\title{
RECOVERING LOST CULTURAL HERITAGE PLACES OF MEXICO. THE CASE OF THE TEMPLE OF JESUS MARIA - MASONIC LODGE OF MERIDA
}

\author{
A. Rodriguez ${ }^{1 *}$, J. Magana ${ }^{2}$ \\ ${ }^{1}$ School of Architecture, Universidad Anahuac Mayab, Merida, Mexico - antonio.rodriguez@anahuac.mx \\ ${ }^{2}$ Independent Researcher - ageofsalem@msn.com
}

Commission II, WG II/8

KEY WORDS: Jesus Maria Temple, Masonic Lodge, Virtual Reconstruction, Colonial Architecture, Neo Mayan Architecture

\begin{abstract}
:
This paper offers, based on the integration of different documentary universes and the extraction of the few physical vestiges, an interpretation of the architectural transformation of the temple of Jesús María-Gran Logia La Oriental Peninsular of Mérida, Yucatán, México, which originally served as a Parish for Black people and mulattos under the advocacy of El Dulce Nombre de Jesús. In the mid-nineteenth century, due to the military clashes during the Second Mexican Empire, this building suffered serious deterioration; reason for which, after the Restoration of the Republic, it was subject to a series of partial reconstructions. During the Mexican Revolution, it was seized and converted into the headquarters of the Gran Logia La Oriental Peninsular, with aesthetic adaptations typical of Neo-Mayan Art Deco, and it was demolished in the 1940s. This contribution highlights the virtual reconstruction that made it possible to indicate the permanencies, changes and losses of this heritage piece in its historical evolution.
\end{abstract}

\section{INTRODUCTION}

Within the set of assets that constitute the built heritage of the city of Mérida, in Mexico, the religious equipment of the New Spain era represents a significant portion in relationship to its peers belonging to other historical stages. It also presents, in addition, high historical-architectural qualities such as the use of materials and technologies of the region, the use of spaces that recognize local bioclimatic features, among others. However, there are buildings from that time that only survive in the form of fragmented memories, since, in addition to not surviving their constructions, their sources of information are scattered or difficult to access. Such is the case of the Jesús María temple, built at the end of the 17th century, which was located a block and a half north of the main square of Mérida, on the current 59th. Street.

This case is also notable due to the amount and unusual nature of transformations suffered throughout its history. In its beginnings (seventeenth century), this building functioned as a parish for blacks and mulattoes under the title of The Sweet Name of Jesus (Victoria, 2014). In the mid-nineteenth century it suffered severe deterioration due to military conflicts that took place during the Second Mexican Empire, so that, after the establishment of the Republic (1867), received a series of partial reconstructions (Diaz, 2014). Later, during the Mexican Revolution, when the building was seized and became the Grand Lodge La Oriental Peninsular, its architecture was subjected to aesthetic adaptations typical of Neomaya Art Deco, being one of the first architectural examples of this style in the State of Yucatán (Urzais, 1997). Finally, in the 1940s, the Masonic Lodge was abandoned and demolished, so to date, what remains is a parking lot service to the aforementioned historic downtown (Novelo, 2002).

Based on the integration of several documentary universes and the extraction of data from the scarce physical vestiges of the site, here is presented an interpretation as complete as possible of the changes in the architecture of this historic property.
To achieve our objective, a longitudinal analysis was designed, that is, the same object of study was observed over time, which would allow us to understand the most important changes in the historical evolution of the property by relating the different evidences obtained. Consistent with Blaise and Dudek (2006), the morphology of architectural objects is conceptualized in the form of pieces of information distributed spatially as well as temporally.

\section{METHOD}

The method used in our work was based on three stages that helped define the historiographical discourse and which led to reveal the modifications, permanence and disappearance of the Jesús María-Gran Lodge La Oriental Peninsular.

\subsection{Heuristic Stage}

The first phase called heuristic stage consisted of the collection of data, through fieldwork and desk job, whether of surveys, graphic documents, architectural plans, etc., information that was, a posteriori, organized and hierarchized in databases. The fieldwork consisted in making photographic and architectural records of the plot where the temple was located.

The documentary compilation consisted of the location and obtaining of primary and secondary information sources about the case study; many of the sources of information came, in order of importance, from the Historical Archive of the Archdiocese of Yucatán (AHAYUC), the Map Library Manuel Orozco y Berra (MMOyB), the Support Centre for the Historical Research of Yucatan (CAIHY), the Reserved Fund of the Newspaper Library "José María Pino Suárez", the Photo Library "Pedro Guerra" of the Autonomous University of Yucatán (UADY) and the Geographic Information System of Mérida (SIG). The documentary sources had a greater weight as inputs for the reconstruction, since the architectural surveys were limited (Figure 1).

\footnotetext{
* Corresponding author
} 


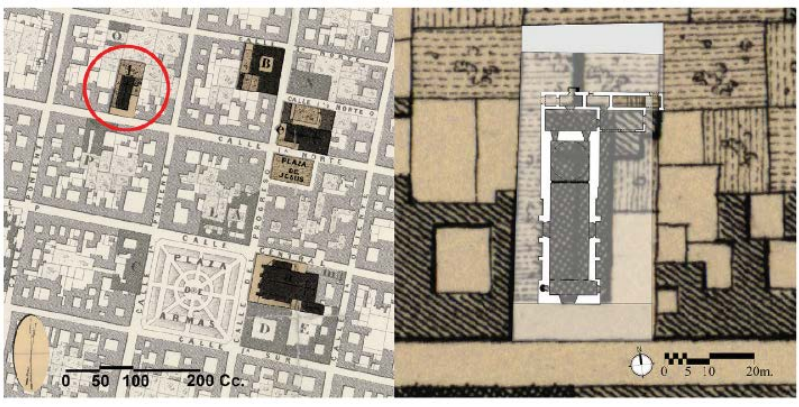

Figure 1. Fragment of the Topographic Map of the City of Mérida (Díaz and Salazar, 1864-1865), depicting the central core of Mérida. According to the original nomenclature, "a" corresponds to the Cathedral Church; "B", the Imperial Commissariat; "E", Jesus church and "l" the Jesús María temple. Scale in Castilian Canes. The overlapping of the plan from the Catalogue of Religious Constructions of the State of Yucatán

(México et al.,1945) with the Topographic Map evidences discrepancy in both the lot and the location of the building. An important feature is the absence of the Virgin's Dressing Room on the north side of the building (staircase access), which does record the 1931 survey.

\subsection{Critical Analysis Stage}

The second phase consisted of so-called critical analysis of the information gathered, assessing its relevance with the help of digital media. The main units of analysis such as the urban layout, architectural alignments or construction components included the analysis of their key features, such as proportions, magnitudes or functions. These units allowed identifying the spatial and temporal links that existed between the different transformations that the building had, as well as making it possible to mark off the main historical phases. All of this was included in a timeline.

\subsection{Hermeneutic Stage}

In the third phase, the hermeneutics, possible causes and consequences of the architectural transformations were determined, and virtual historical reconstructions were elaborated as graphic hypotheses of synthesis for the depiction of such transformations. In the Semantic Models, the different architectural elements were visually integrated, following this work sequence:

Selection. The sources that distinguished most effectively the elements or the relevant features of the building were chosen.

Evaluation. The diverse indications were confronted by means of photogrammetric methods designed ad hoc, and in this way their coincidences and discrepancies were checked. Derived from this documentary comparison, archival images and historical surveys together confirmed a series of key architectural features (Figures 2 \& 3).

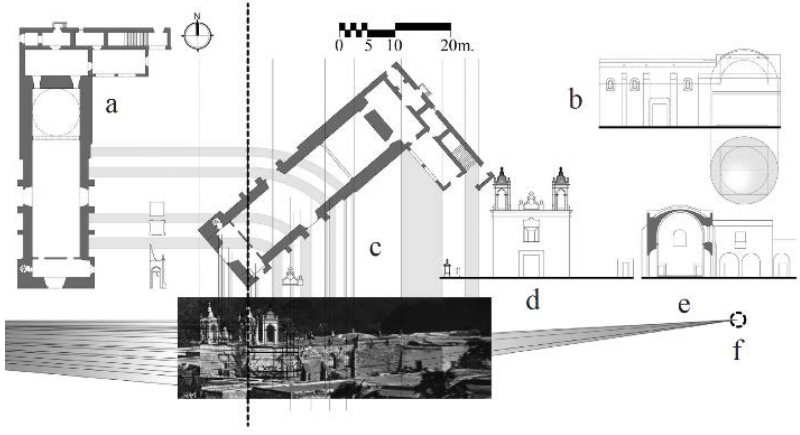

Figure 2. Photogrammetric analysis of the Jesús María temple, from the Catalogue in subsections (a, e); photograph from the Photo Library "Pedro Guerra" of the Autonomous University of

Yucatán (1883 ca.) (c); new orthogonal projections (d, b) obtained by geometric deduction from the original "perspective rays" (f).

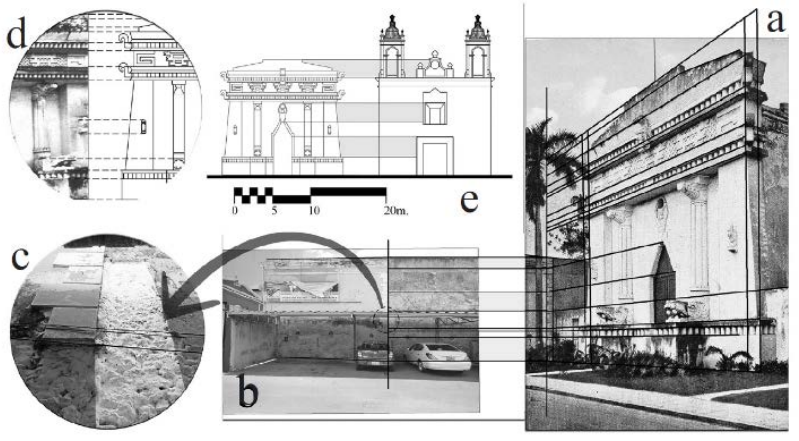

Figure 3. Photogrammetric analysis of the Grand Lodge The Oriental Peninsular based on the original photographs (a, d) and physical remains present in the adjoining walls (c, b) to give a reference and obtain the projections.

Extraction. It consisted of gathering data from previous evaluation and confrontation operations with a high degree of reliability. These data were already part of hypothetical reconstruction models.

Exploitation. The extracted data was transformed into graphic hypotheses with 2D and 3D software.

In a transversal manner, a constant updating of the digital models was necessary every time the data was renewed or new findings were integrated. To clearly demonstrate the origin of the sources used, in each part of the models, a series of graphic-deontological codes established by Rodríguez (2012) were included (Figure 4). As scientific products, the reconstruction images have the opportunity to justify their proposal given the available information, which can be revised by the readers to be improved in subsequent cycles. 


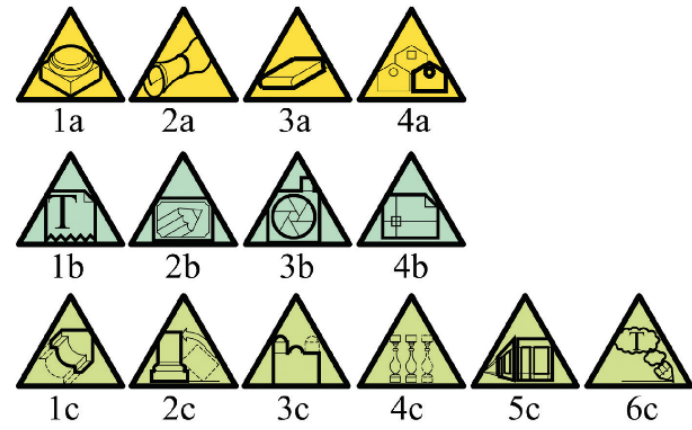

Figure 4. Deontological code to show the origin of each part of the reconstruction models. The first row indicates the type of source (physical evidence, primary source, historiographical source and typological study); the second, the type of document

(text, drawing, photograph, plan), the third indicates the modality of reconstruction (by geometric continuity, virtual anastilosis, symmetry, pattern, photogrammetric restitution or free interpretation).

\section{RESULTS}

3.1 The foundation: the temple The Sweet Name of Jesus (1684-1867)

During the prelature of the bishop of Yucatan Juan Cano Sandoval (1682-1695) was founded, in 1684, in Merida, the parish of The Sweet Name of Jesus, also called The Holy Name of Jesus, in a site near the Square of Jesus. To this church, the bishop moved a parish of blacks and mulattoes located in the Hermitage of Santa Lucia, three blocks north of the Main Square (Victoria, 2014). Originally, the Square of Jesús parish was financed by the governor Bruno Tello de Guzmán (Cetina, 1984). Over time (from its foundation until the second half of the 19th century), this chapel became a Marian shrine, that is, a temple "dedicated to remembering some prodigy, episode or mystery of the life of the Virgin Mary" (Chanfón, 1997).

The chapel of El Dulce Nombre de Jesús probably consisted of a presbytery roofed with a sail vault, followed by a masonry barrel vaulted nave and ending with a facade crowned by two towers with a simple body. Being a late Marian sanctuary (second half of the nineteenth century) it is possible that at this stage it did not have the Virgin's Dressing Room, nor the premises of their worship as stairs or adjoining rooms: it only had a back sacristy (Figure 5).

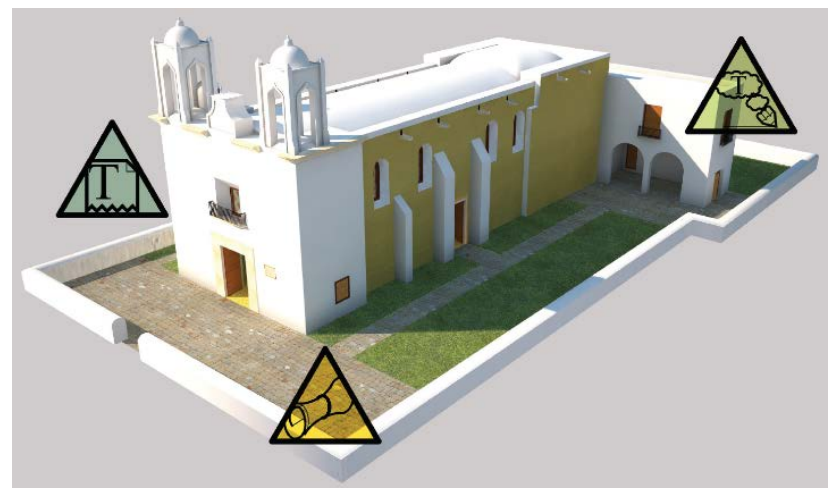

Figure 5. Reconstructive hypothesis of the El Dulce Nombre de Jesús temple, based on documentary sources and retrospective inference from the subsequent stages.

\subsection{The Reconstruction by Crescencio Carrillo y Ancona (1867-1910)}

At some point between 1823 and 1846, when El Dulce Nombre de Jesús no longer functioned as a parish of castes (Victoria, 2014: 152), it changed its name to that of Jesús María. Later, during the Second Empire of Maximilian of Habsburg, the military struggles between republicans and imperialists reached Yucatan (Pavia, 1897). In 1867, the troops of General Manuel Cepeda Peraza besieged Mérida in the attempt to defeat the imperialist forces of José Salazar Ilarregui (Manzanilla, 1888). During the siege, many buildings were damaged by artillery fire (Pavia, 1897), including the Jesús María temple, particularly its towers (Cetina, 1984).

In 1870, after the war, priest José Guadalupe Patrón began negotiations to begin reparations (ACASY-AHAYUC 18721873), but he was soon relieved of his duties by Chaplain Crescencio Carrillo and Ancona, who prepared a list of repair works. The works included the following: repair the sacristy as well as the rooms in both low and high stories; rebuild altarpieces in the presbytery and close it with a fence; repair and paint vault and walls; repair the choir; build a cypress altar at the centre of the presbytery; close the atrium with a blacksmith's fence and place two bells in the towers (ACASY-AHAYUC 1875). The donations collected were destined for the purchase of construction materials and workmanship (ACASY-AHAYUC 1876), counting other income from burial rights.

The temple, likewise, was converted at the request of Carrillo and Ancona, in the seat of a new symbol of regional identity: the cult of the Virgin of the Immaculate Conception (Carrillo, 1875), under the name of Nuestra Señora de Yucatán (Canto, 2008), knowing the building from then on as the Patron's Sanctuary, introducing the aforementioned Virgin' Dressing Room. The reopening took place in 1907.

Outside, the atrium was equipped with a blacksmith gate supported by parapets and masonry pillars (Novelo, 2002). The main façade was restored and maintained its original proportions, with two bell towers with canopied arches, bell-shaped domes and corner reliefs crowned with burner cups. The central parapet of the façade was able to house a cartouche or relief image of La Inmaculada, although the documentary evidence is not clear; the rest of the temple was given general maintenance on doors, windows and paint. On the other hand, the interior acquired new chromatic features, altars, decorative elements, furniture and liturgical equipment (Cetina, 1984) (Figure 6).

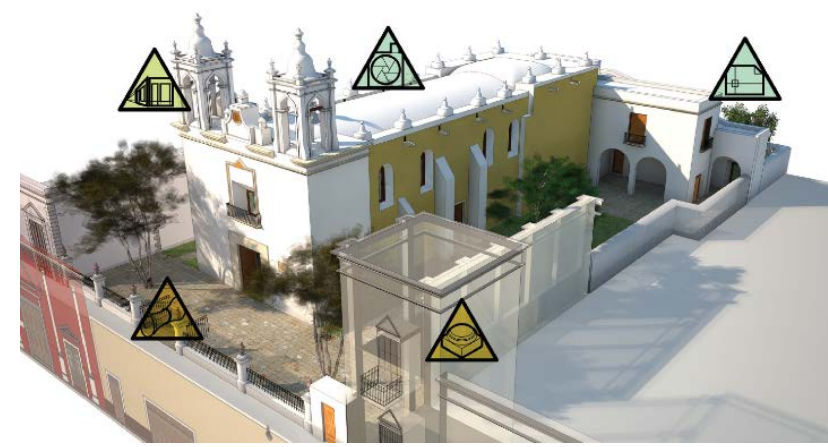

Figure 6. Virtual volumetric reconstruction of the Jesús María temple, evidencing the sources of the various parts of the model.

Indoors, ten pilasters stand out distributed in the walls of the nave with Corinthian order features. The main altar was completely remodelled, possibly in a neoclassical style, a cypress was 
included in the centre for a Eucharistic Tabernacle and the presbytery area was delimited with a wooden railing, at the point of the triumphal arch. Finally, the interior painting was changed to light blue on the walls given its Marian nature; a series of simulated painted coffered ceilings covered the intrados of the vault and the cupola as a trompe l'oeil (Figure 7).

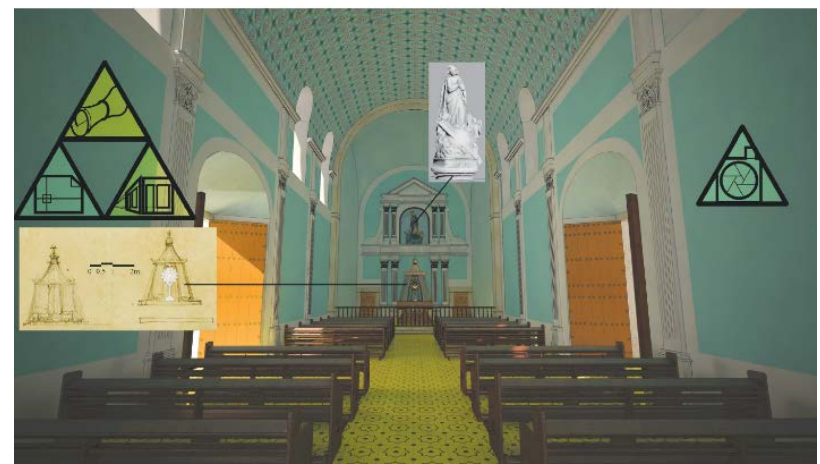

Figure 7. Interior virtual reconstruction of the Jesús María temple. It includes the project of cypress; a canopy or umbraculum (veil in pavilion's form) can be seen. The graphic scale corresponds to the dimensions of the original drawing. The original image of Our Lady of Yucatan is preserved in the Cathedral of Mérida, so it was possible to perform laser scans and then restore it virtually to its primitive site: the Dressing

Room's Niche; Source: (ACASY-AHAYUC 1876).

\subsection{The Conversion: Grand Lodge La Oriental Peninsular of Manuel Amábilis (1916-decade 1940)}

Under the command of Venustiano Carranza, General Salvador Alvarado was sent to take Yucatan, who entered Mérida in March 1915 (Díaz, 2014). Alvarado immediately took charge of the governorship of the State and on December $15^{\text {th }}$, 1915, he declared the expropriation of "private property for the sake of public utility" (Avila, 1915): Jesús María was included among them. Shortly before the expropriation, Alvarado appointed the architect Manuel Amábilis as Director of School Buildings on December $4^{\text {th }}$, 1915, and he was in charge of the transformations that were undertaken in this venue (Ávila, 1915). The lodge had already been founded since October 1911, under the name of Respectable Symbolic Lodge Renaissance No. 1. of Early Grand Scottish Rite.

The second semester of 1916 was the probable period for the building works of the lodge. The exterior modifications affected almost exclusively the façade, since much of the structure was preserved intact. Outside, the atrium of the old temple was destroyed along with the fence and three walkways paved with stone tiles were placed leading to the interior of the property: a central way to enter the main nave and two secondary ones to access lateral alleys.

The main façade was the element that had the most modifications of the entire property, since it was remodelled in the Neomaya Art Deco style, superimposing the new façade on the existing structure (Figure 8). To achieve this objective, the demolition works included the two bell towers, the main access, the coral window and the upper parapet, thus maintaining the structural wall (Urzáiz, 1997). It is possible that the main door was partially reused, since the new door reached 7 meters height against 2.40 meters of that original: this was how Amabilis got an opening with similar proportions to the false arches placed in the Palaces of the ancient Maya (Diaz, 2014).

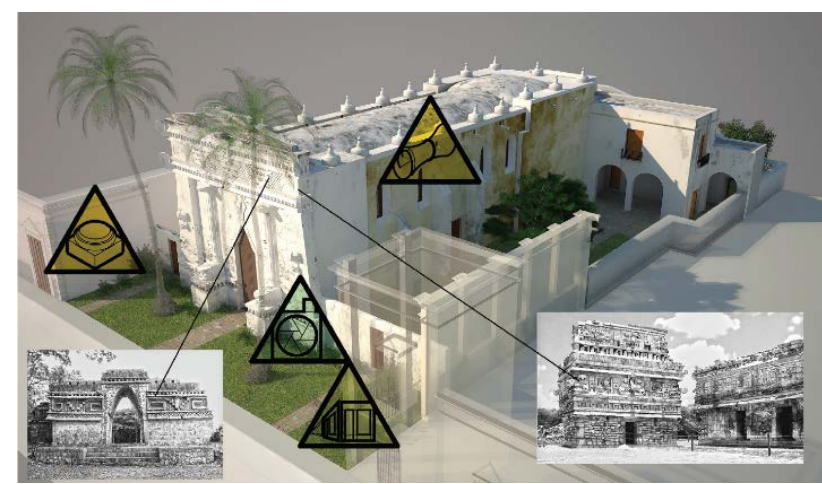

Figure 8. Virtual volumetric reconstruction of the Grand Lodge The Peninsular Oriental. Possible archaeological references that the architect Amábilis used in the composition of the façade are included, as in Labná (left) and Chichen Itza (right).

On the other hand, the nave presents radical transformations. Under the barrel vault a flat ceiling suspended by transverse iron beams was placed (Mexico et al., 1945), so that the original roof and the windows were completely hidden (Figure 9). This modification completely changed the spatial feeling since the natural ventilation and lighting were cancelled (with the exception of the side doors). The height of the interior space was reduced to practically half and the altarpiece of the presbytery was completely removed.

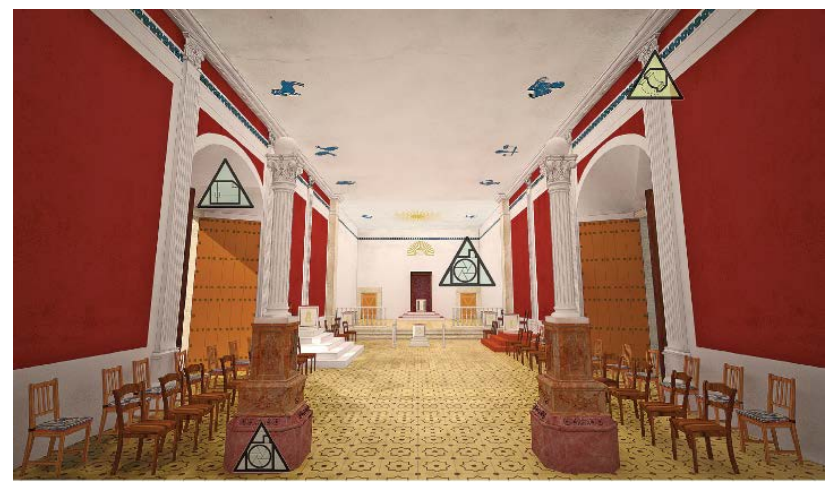

Figure 9. Interior reconstruction of the Grand Lodge The Oriental Peninsular, based on the photograph published in The Voice of the Revolution (1917) and the previous model of the temple of Jesus Mary.

Due to the amplitude of the main nave, three new spaces were created in a linear arrangement: the Room of Errant Steps, the Atrium and the Temple. The Room of Errant Steps was the immediate space after the main access. Then there was the Atrium, a space of transition in which the freemasons concentrated and prepared. The next space was delimited by the symbolic division offered by the two columns "Joachim" and "Boaz", marking the beginning of the Temple. Finally, in the Temple, all the elements necessary for the cult were placed, such as the Place of the Experts, the Standard Bearer, the Master of Ceremonies and the two Guards (Rodríguez, 2006).

In this space, the stairway of the presbytery was used to place the Hospitable, Treasurer, Speaker and Secretary, divided by a handrail that emphasized the throne of the Venerable Master. The temples are usually totally enclosed spaces, however, Amabilis did not cancel the side doors of the nave and located the "J" and "B" columns very close to them. In this way, the atrium and the 
temple shared the same space without the physical division required by the freemasons (Respectable Lodge Symbolic Centaur No. 9-96, 2009).

Over the years, several conflicts and schisms would be created within the Grand Lodge La Oriental Peninsular. One occurred in September 1923 when several of its members were expelled, including Amabilis, who moved to another building on $61^{\text {st }}$ Street in the Santiago neighborhood (Díaz, 2014). The temple was abandoned and finally demolished in the mid 1940's with the promise of building the City Theater, a project that never occurred.

\section{CONCLUSIONS}

It is remarkable the shortage in the published local historiography that deals with the urban inter-parish temples of Merida city in general, and the temple of Jesús María-Gran Lodge La Oriental in particular, hence the references of this work have been mainly sources of archive, together with the very few monumental remnant references. The grouping of scattered indices thus formed a starting documentary corpus to support the working hypotheses. It should be noted that the nature of the documentation of the first stages was closer to the archive sources, while the documentary support of the most recent ones is based on surveys and photographs. We were able to differentiate the sources or "key role" documentary evidences such as the architectural surveys and the few photographs, and the "cast" ones as descriptions of furniture, among others.

The work of historical reconstruction based on said documentary integration, presents in an unprecedented and detailed way morphological-architectural, functional and spatial features of the vanished building; in addition to the documentary findings, it presents two key contributions in the methodological order:

- Critically confront documentary sources with the help of digital technology. This allowed to discover inaccuracies in documents such as the Topographic Map of 1864 (Díaz and Salazar 18641865 ) or the 1931 surveys (Mexico et al., 1945) against the photographic evidence of Pedro Guerra (1883 ca. and 1917), iterating increasingly accurate approaches that can be enriched with subsequent contributions.

- Demonstrate, through deontological codes, the origin of each part of the reconstruction models, in an effort to contribute with "buildable" proposals, with the possibility of evolving, through the auditing of the readers themselves. In this sense, synthetic and semantic models images can be considered not as ends, but as starting points, since they allow detonating new questions and knowledge.

Additionally, interactive virtual worlds were tested, which was revealed as an interesting experience not only didactic but also scientific, being able to evaluate very closely the perception of the details of the virtual reconstruction work (Figure 10).

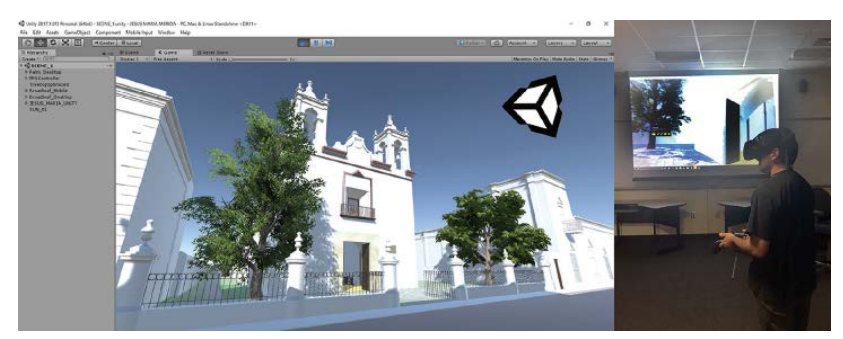

Figure 10. First pilot experiences with virtual interactivity at the Missouri State University (USA), using as a basis the historical phase of the reconstruction of the Jesús María temple (second half of the $19^{\text {th }}$ century); the Unity videogame platform and the HTC Vibe hardware were handled.

This research work aims to start other efforts to learn more about the disappeared heritage in the region; in the case of the Jesús María Temple - Gran Logia La Oriental Peninsular it is possible to carry out archaeological studies that corroborate the hypothesis of the location of the structures and underlying graves in the site. The implications of the study we believe may arouse greater interest to know this and other similar examples that gradually complete the memory of the urban fabric, in understandable terms and in formats that facilitate its dissemination. Its importance lies in its proposal to integrate different universes of information into a single coherent discourse that honestly reveals what is found or what is missing or hypothetical, allowing a more fruitful and effective collaborative work to advance in the knowledge of the case studies.

\section{ACKNOWLEDGEMENTS}

To the director of the Historical Archives of the Archdiocese of Yucatán (AHAYUC, Mexico) the lawyer Héctor A. Cárdenas Angulo; the coordinator of AHAYUC, Mr. Carlos A. Mendoza Alonzo; to the curator of the Conservation, Restoration and Binding Center of Yucatan (CCREYUC, Mexico), Mr. Israel L. Cetina Nahuat; as well as Héctor Domínguez, Rodrigo García de Gyves and Jorge Ruiz Posadas, students providing social services at the School of Architecture of the Anahuac Mayab University in Yucatan, Mexico, and the architect Mario Rejón Torres.

\section{REFERENCES}

ACASY-AHAYUC, 1872-1873. Cofradía de la Inmaculada Concepción. Recibos de trabajos para el templo Jesús María, remitidos por el Prbro. Crescencio Carrillo y Ancona, Mérida, Manuscrito, Archivo Carrillo y Ancona del Seminario de Yucatán, Archivo Histórico de la Arquidiócesis de Yucatán (ACASY-AHAYUC), Sección Gobierno, Serie Obispos, Box 462, file. 1, f. 56 (Gobierno Pastoral, Sr. Alva y Franco).

ACASY-AHAYUC, 1875. Papeles relativos a Jesús María, Mérida, Manuscript, Archivo Carrillo y Ancona del Seminario de Yucatán, Archivo Histórico de la Arquidiócesis de Yucatán (ACASY-AHAYUC), box 7, file 67.

ACASY-AHAYUC, 1876. Memoria del Mejoramiento de la Iglesia de Jesús y María, Mérida, Manuscrito, Archivo Carrillo y Ancona del Seminario de Yucatán, Archivo Histórico de la Arquidiócesis de Yucatán (ACASY-AHAYUC), box 7, file 67.

Ávila, Florencio, 1915. Diario Revolucionario, Mérida, Oficina de Información y Propaganda Revolucionaria. 
Blaise, J. and Iwona Dudek, 2006. Modélisation informationnelle, Marsella, Modélisation informationnelle pour l'architecture patrimoniale (MIA) - Centre National de la Recherche Scientifique.

Bretos, M., 1987. Arquitectura y arte sacro en Yucatán, 15451823, Mérida, Producción Editorial Dante.

Bretos, M., 1992. Iglesias de Yucatán, Mérida, Producción Editorial Dante.

Canto, E., 2008. Los partidarios del proyecto imperial en la península de Yucatán. De la instauración monárquica a la última conciliación republicana (1863-1898), Mérida, Patronato Pro Historia Peninsular de Yucatán (ProHispen).

Carrillo y Ancona, C., 1875. Archicofradía y Escapulario Azul de la Inmaculada Concepción, Mérida, Imprenta del Comercio de N.R.A.

Carrillo y Ancona, C., 1878. La civilización yucateca o el culto de la Virgen María en Yucatán: disertación histórico-religiosa sobre el culto de la Purísima Virgen entre los yucatecos desde la conquista, y sobre su influencia social hasta nuestros días, Mérida, Miguel Espinosa Rendón.

Carrillo y Ancona, C. and Víctor Suárez Molina, 1979 [1898]. El obispado de Yucatán: Historia de su fundación y de sus obispos desde el siglo XVI hasta el XIX, seguida de las constituciones sinodales de la diócesis y otros documentos relativos, Mérida de Yucatán, Fondo Editorial de Yucatán.

Cetina, J., 1984. Historia gráfica. Mérida de Yucatán, 15421984, Mérida, Ayuntamiento de Mérida 1982-1984.

Chanfón, C., 2001. Historia de la arquitectura y el urbanismo mexicanos, volume II, book II México, Universidad Nacional Autónoma de México.

Díaz, A., Salazar, J. 1864-1865. Plano Topográfico de la Ciudad de Mérida [Map], Map Library Manuel Orozco y Berra (Servicio de Información Agroalimentaria y Pesquera), [http://w2.siap.sagarpa.gob.mx/mapoteca/mapas/909-OYB7264-A.jpg]

Díaz, M., 2014. "El arte monumental del socialismo yucateco (1918-1956)”, [Ph.D. Thesis], Mérida, Centro de Investigaciones y Estudios Superiores en Antropología Social (CIESAS),[http://repositorio.ciesas.edu.mx/handle/123456789/28 9?show=full].

Fraternidad No 10, 2016. Historia de las logias de la jurisdicción, de la Gran Logia Unida La Oriental Peninsular, [http://fraternidad10.org/semblanza-historica-de-la-rlsrenacimiento-no-1/].

García Preciat, J. 1977 [1944]. Historia de la Arquitectura, Enciclopedia Yucatanense, Vol. IV, Mérida, Edición oficial del Gobierno de Yucatán.

Grosjean, S., 2015 July 24th., Salvador Alvarado, el 'gran destructor' de Yucatán, Milenio, [https://sipse.com/milenio/rosto-oculto-salvador-alvaradodestruccion-patrimonio-historico-yucatan-138917.html].
Guerra, P., 1883 ca. Templo de Jesús María [Photography], Mérida, Photo Library "Pedro Guerra”, Universidad Autónoma de Yucatán (key 1A06210.jpg).

Guerra, P., 1917. Una noche de tenida en el interior del Templo Masónico de la calle 59 de esta ciudad, [Photography], La voz de la Revolución, Mérida, January 17th., p.23.

Hiebel, G. and Hanke, K., 2017. DIGITAL WORKFLOWS FOR A 3D SEMANTIC REPRESENTATION OF AN ANCIENT MINING LANDSCAPE. The International Archives of the Photogrammetry, Remote Sensing and Spatial Information Sciences, 42(5), 355-359. doi:10.5194/isprs-archives-XLII-2W5-355-2017

Manzanilla, Y., 1888. Recuerdos de la campaña de los republicanos contra el Imperio, Mérida, author's edition.

Mérida en la Historia, 2018.

[https://www.facebook.com/pg/MeridaEnLaHistoria/photos/?ref =page_internal].

Mex, M., 2015. Reconstruyendo la historia de las logias masónicas en Yucatán, Unicornio, Por Esto!, Mérida, August 9th., 6.

México, J. Fernández, B. L Vega, M. J. Rubio, P. J. García and V. A. Barrera, 1945. Catálogo de Construcciones Religiosas del Estado de Yucatán, México, Talleres Gráficos de la Nación.

Novelo, A., 2002. Mérida, la de Yucatán, Mérida, Instituto de Cultura de Yucatán.

Pavía, L., 1897. El imperio en la península yucateca por Lázaro Pavía. Apuntes para la historia 1861-1867, México, Imprenta de Eduardo Dublán.

Respetable Logia Simbólica Centauro No. 9-96, 2009, March 26th., Liturgia del Grado de Aprendiz, Respetable Logia Simbólica Centauro No. 9-96. R. $\cdot$.E. $. A . \cdot A . \cdot$, [https://centauro996.wordpress.com/2009/03/25/liturgia-delgrado-de-aprendiz/].

Rodríguez, P., 2006. Plano de distribución de una logia, Masonería al descubierto, [http://www.peperodriguez.com/Masoneria/Masoneria_plano_logia.htm].

Rodríguez, A., 2012. La reconstrucción histórica virtual de la Plaza Mayor de Mérida, Yucatán. Siglos XVI-XIX. Una aproximación al patrimonio cultural urbano arquitectónico por medio de las herramientas de computación visual (Ph.D. Thesis), México City, UNAM.

Sirgado, J., 1908. Crónica Íntima de la Solemne Fiesta Religiosa celebrada en la Iglesia de Jesús María de Mérida, el 13 de noviembre de 1907, Mérida, Imprenta Gamboa Guzmán.

Urzáiz, E., 1997. Arquitectura en tránsito. Patrimonio arquitectónico de la primera mitad del siglo XX en la ciudad de Mérida, Yucatán, Mérida, Ediciones de la Universidad Autónoma de Yucatán (UADY).

Victoria, J., 2014. Africanos y afrodescendientes en la Mérida de Yucatán, México. Dos apuntamientos (siglos XVI a XIX), $\begin{array}{llll}\text { Fronteras de la Historia, } 19 & \text { (2):148-174, }\end{array}$ [http://doi.org/10.22380/2027468828]. 